\title{
PENGEMBANGAN MEDIA PEMBELAJARAN TITIK GARIS BIDANG (TGB) UNTUK SISWA TUNAGRAHITA RINGAN KELAS VIII SMPLB
}

\author{
Linda Ardani Afriliziana ${ }^{1}$, Maimunah $^{2}$, Susda Heleni ${ }^{3}$ \\ ${ }^{1,2}$ Program Studi Pendidikan Matematika, Universitas Riau \\ Email: linda.ardani5063@ student.unri.ac.id
}

\begin{abstract}
Abstrak:
Tujuan penelitian yang dilakukan adalah untuk menghasilkan media pembelajaran matematika titik, garis, bidang yang disingkat dengan TGB pada materi balok dan kubus untuk siswa tunagrahita ringan kelas VIII SMPLB Pekanbaru. Media pembelajaran yang dikembangkan berupa media pembelajaran TGB dan buku petunjuk penggunaan media. Metode penelitian yang digunakan adalah model pengembangan Borg and Gall dengan sepuluh tahapan yaitu: (1) potensi dan masalah, (2) mengumpulkan informasi, (3) desain produk, (4) validasi desain, (5) revisi desain, (6) ujicoba produk, (7) revisi produk, (8) ujicoba pemakaian, (9) revisi produk, dan (10) produksi masal. Penelitian ini dilakukan sampai tahap ujicoba produk, karena pandemic Covid-19 untuk tahap tujuh sampai sepuluh membutuhkan cakupan yang luas serta waktu yang lama. Hasil analisis data validasi diperoleh ratarata penilaian untuk media pembelajaran dan buku petunjuk penggunaan media adalah 2,77 dengan kriteria valid. Hasil analisis data praktikaitas diperoleh dari hasil angket respon siswa terhadap media, diperoleh persentase rata-rata $100 \%$. Berdasarkan hasil analisis data dan pembahasan dapat disimpulkan bahwa media pembelajaran matematika yang dikembangkan telah memenuhi kriteria valid yaitu layak untuk digunakan dan praktis yaitu mudah untuk digunakan.
\end{abstract}

Kata Kunci:, Penelitian Pengembangan, Media TGB, Valid dan Praktis

\begin{abstract}
:
The purpose of the research conducted is to produce math learning media field line and point (TGB) on the material of cuboid and cube for mild intellectual disability $8^{\text {th }}$ in SMPLB Pekanbaru. The developed media learning are TGB method and manual book. The research methods Borg and Gall development models with ten stages: (1) Potential and problems; (2) Collect information; (3) Product design; (4) Design validation: (5) design revisions; (6) Product testing; (7) Product revisions; (8) Usage testing; (9) Product revisions; and (10) mass production. This research is conducted until product testing stage, due to the Covid-19 pandemic it is hard to continue the research from $7^{\text {th }}$ to $10^{\mathrm{th}}$ stages. Apparantly it needs wider coverage and more sufficient term on making this research works fully at times like this. The results of the data validation analysis show the average assessment for the learning media and the manual book is 2.77 with valid criteria. The results of the analysis of the practical data were collected from the results of the students response to the media, with average percentage of $100 \%$. Based on the results of data analysis and discussion can be concluded that the mathematics learning media developed has fulfilled valid criteria that is worthy to be used and practical that is easy to use.
\end{abstract}

Keywords: Development Research, Media Field Line and Point (TGB), Valid and Practical

\begin{tabular}{l} 
Pendahuluan \\
\multicolumn{1}{c}{ SLB (Sekolah Luas Biasa) } \\
merupakan salah satu jenis satuan \\
pendidikan di Indonesia yang diatur oleh \\
peraturan menteri pendidikan dan \\
kebudayaan Republik Indonesia nomor 4 \\
tahun 2018 pada pasal 1 ayat (1). Menurut
\end{tabular}

Petunjuk Pelaksanaan Sistem Pendidikan Nasional Tahun 1993, Lembaga pendidikan SLB adalah lembaga pendidikan yang bertujuan membantu siswa yang menyandang kelainan fisik dan/ atau mental, prilaku dan sosial agar mampu mengembangkan sikap, pengetahuan dan 
keterampilan serta agar dapat mengembangkan kemampuan dalam dunia kerja atau mengikuti pendidikan lanjutan.

SLB adalah suatu sekolah yang dikhususkan untuk anak-anak yang berkebutuhan khusus. Anak berkebutuhan khusus adalah anak yang berkelainan yaitu anak-anak yang berbeda secara signifikan dari anak-anak normal lainnya dan membutuhkan pendidikan yang khusus (Lilik, 2014). Pengelompokkan siswa SLB di Indonesia ada empat macam dan salah satunya adalah untuk siswa yang menyandang status tunagrahita dan siswa ini dikelompokkan dalam SLB bagian C. Siswa tunagrahita merupakan anak yang memiliki tingkat intelektual dibawah ratarata (Febrisma, 2013).

Menurut American Association on Mental Retardation (AAMR) dalam Soendari (2006) klasifikasi anak tunagrahita dibedakan menjadi 4 tingkatan yaitu: 1) anak yang memiliki IQ 55-70 dikatakan tunagrahita ringan. 2) IQ 40-54 dikatakan tunagrahita sedang. 3) IQ 25-39 dikatakan tunagrahita berat. 4) IQ $\leq 24$ dikatakan tunagrahita sangat berat. Menurut Amin dalam Usti (2013) anak tunagrahita ringan memiliki pola pikir yang lambat tetapi masih dapat memahami pelajaran akademik. Kelompok tunagrahita ringan memiliki kemampuan di bawah rata-rata anak normal sehingga mereka masih bisa belajar menulis, membaca dan berhitung sederhana.

Matematika merupakan salah satu mata pelajaran yang sampai saat ini masih dianggap sulit untuk siswa (Nani Restati Siregar, 2017). Mata pelajaran matematika merupakan salah satu mata pelajaran yang harus diberikan di setiap jejang sekolah. Siswa tunagrahita juga belajar matematika sesuai mata pelajaran di sekolah dengan menggunakan buku paket yang dikhususkan untuk siswa SLB tunagrahita. Pembelajaran bagi siswa tunagrahita di sekolah haruslah akomodatif dalam segi materi, metode, maupun media pembelajaran, sehingga dapat memfasilitasi perbedaan yang ada antara siswa regular dengan siswa tunagrahita (Dhelpie, 2006).
Menurut Tri Murdiyanto, dkk (2014) media merupakan salah satu solusi untuk menanamkan konsep matematika dengan mudah terutama untuk siswa-siswa yang berkebutuhan khusus yaitu tunagrahita, namun pada kenyataannya penggunaan media dalam pembelajaran masih jarang dikarenakan beberapa alasan salah satunya adalah karena sulit mencari media yang tepat. Hasil observasi yang diperoleh di SLB Pelita Hati Pekanbaru menunjukkan bahwa masih jarang guru menggunakan media dikarenakan media pembelajaran yang dimiliki sekolah tidaklah beragam sehingga hanya bisa digunakan pada materi-materi tertentu saja.

Materi balok dan kubus adalah salah satu materi yang sulit dipahami siswa, baik siswa di sekolah umum apalagi di sekolah luar biasa. Pada sekolah umumpun menggunakan media untuk mengkonkritkan daya abstrak dari materi tersebut. Seperti penelitian yang dilakukan Fitriyani, dkk (2020) menggunakan media berbasis computer pada materi kesebangunan dan kekongruwenan pada siswa SMP karena sulitnya siswa memahami materi tersebut. Beberapa guru menggunakan media hanya sebatas mencontohkan bentuk balok dan kubus saja sehingga membuat siswa kesulitan dalam memahami materi tersebut.

Peneliti mengembangkan media pembelajaran Titik, Garis, Bidang (TGB) yang dapat digunakan pada materi balok dan kubus dimana materi tersebut disesuaikan dengan kompetensi dasar yang terdapat pada pelajaran matematika kelas VIII dan media TGB ini bertujuan untuk menunjukkan bagian titik, garis, dan bidang pada balok dan kubus. Peneliti juga memilih materi balok dan kubus dikarenakan materi ini tepat jika menggunakan media pembelajaran khususnya untuk siswa tunagrahita dan dari segi fasilitas sekolah juga masih minim fasilitas berbasis computer sehingga sekolah bisa dengan mudah menyediakan media pembelajaran.

\section{Metode Penelitian}

Penelitian dan pengembangan ini dengan model pengembangan Borg \& Gall. Tahap yang dilakukan dalam penelitian ini 
hanya sampai pada tahap ujicoba produk, artinya hanya 6 tahap dari 10 tahapannya dikarenakan pandemic Covid-19. Tahap pertama adalah tahap potensi dan masalah dalam mengembangkan media pembelajaran dilakukan dengan melakukan observasi dan wawancara di SMPLB Pelita Hati Pekanbaru. Tahap kedua yaitu tahap pengumpulan nformasi, yang digunakan sebagai bahan perancangan prototipe, sehingga diharapkan dapat mengatasi permasalahan yang ada pada siswa tunagrahita dalam pembelajaran matematika. Tahap keempat adalah desain produk yaitu melakukan penilaian terhadap media pembelajaran sehingga diketahui kelebihan dan kelemahannya. Pada tahap kelima yaitu tahap validasi desain adalah proses kegiatan untuk menilai rancangan poduk secara rasional. Validasi desain dilakukan oleh dosen ahli dan guru tunagrahita. Hasil validasi kemudian dianalisis dan direvisi sesuai dengan saran validator. Tahap keenam yaitu ujicoba terbatas yang dilakukan pada dua orang siswa SMPLB Pelita Hati Pekanbaru dan satu orang siswa SMPLB Negeri Pembina Pekanbaru. Setelah media pembelajaran diujicobakan, peneliti memberikan angket respon siswa untuk memperoleh data respon siswa terhadap penggunaan media pembelajaran titik, garis, bidang pada materi balok dan kubus dengan membacakan pertanyaan angket respon tersebut.

Teknik analisis data pada penelitian ini adalah teknik analisis data kuantitatif yang terdiri dari analisis data hasil validasi oleh validator dan analisis data hasil angket respon.. Kriteria validitas media pembelajaran dapat dilihat pada Tabel 1 .

\section{Tabel 1. Persentase Penilaian Skor} Kevalidan Produk

\begin{tabular}{cll}
\multicolumn{3}{c}{ Kevalidan Produk } \\
\hline No & $\begin{array}{c}\text { Tingkat } \\
\text { Penilaian } \\
\text { (dalam persen) }\end{array}$ & Kriteria Valid \\
\hline \multirow{1}{*}{1} & $80<x \leq 100$ & $\begin{array}{l}\text { Sangat Valid } \\
\text { (tidak perlu } \\
\text { revisi) }\end{array}$ \\
& &
\end{tabular}

\begin{tabular}{lll}
\hline 2 & $60<x \leq 80$ & $\begin{array}{l}\text { Valid (tidak } \\
\text { perlu revisi) }\end{array}$ \\
\hline 3 & $40<x \leq 60$ & $\begin{array}{l}\text { Kurang Valid } \\
\text { (revisi) }\end{array}$ \\
\hline 4 & $20<x \leq 40$ & $\begin{array}{l}\text { Tidak Valid } \\
\text { (revisi) }\end{array}$ \\
\hline 5 & $0<x \leq 20$ & $\begin{array}{l}\text { Sangat Tidak } \\
\text { Valid (revisi) }\end{array}$ \\
\hline $\begin{array}{l}\text { Keterangan: } \\
x=\text { Persentase penilaian }\end{array}$ \\
\hline
\end{tabular}

Sumber: Sugiyono, 2017

Media pembelajaran dikatakan valid jika nilainya lebih dari $60 \%$.

Kriteria kepraktisan media pembelajaran dapat dilihat pada Tabel 2 .

Tabel 2. Persentase Penilaian Skor Kepraktisan Produk

\begin{tabular}{ccl}
\hline No & $\begin{array}{c}\text { Tingkat } \\
\text { Penilaian }\end{array}$ & Kriteria Praktis \\
\hline 1 & $\begin{array}{c}80<x \leq 100 \\
\%\end{array}$ & $\begin{array}{l}\text { Sangat Praktis } \\
\text { (tidak perlu } \\
\text { revisi) }\end{array}$ \\
\hline 2 & $\begin{array}{c}60<x \leq 80 \\
\%\end{array}$ & $\begin{array}{l}\text { Praktis (tidak } \\
\text { perlu revisi) }\end{array}$ \\
\hline 3 & $40<x \leq 60$ & $\begin{array}{l}\text { Kurang Praktis } \\
\text { (revisi) }\end{array}$ \\
\hline 4 & $20<x \leq 40$ & $\begin{array}{l}\text { Tidak Praktis } \\
\text { (revisi) }\end{array}$ \\
$\%$ & & $\begin{array}{l}\text { Sangat Tidak } \\
\text { Praktis (revisi) }\end{array}$ \\
\hline 5 & $0<x \leq 20 \%$ \\
\hline Keterangan: $x=$ Persentase penilaian
\end{tabular}

Sumber: Sugiyono, 2017

Media pembelajaran dikatakan praktis jika penilaiannya lebih dari $60 \%$. 


\section{Hasil dan Pembahasan \\ Tahap Potensi dan Masalah}

Pada tahapan ini peneliti memperoleh potensi dan masalah melalui wawancara dengan satu orang guru SMPLB-C Pelita Hati Pekanbaru, dua orang guru SMPLB Pembina Pekanbaru, dan satu kepala sekolah SMPLB Pembina Pekanbaru yang selanjutnya potensi dan masalah tersebut dirumuskan dan dianalisis (need analysis). Kesimpulan dari wawancara terhadap ketiga narasumber tersebut, peneliti dapat menemukan potensi dan masalah. Potensi yang ditemukan dalam penelitian ini adalah kurangnya penggunaan media dalam proses pembelajaran terutama dalam pembelajaran matematika. Masalah yang peneliti temukan yaitu siswa tunagrahita mengalami kesulitan dalam memahami pembelajaran matematika.

\section{Tahap Mengumpulkan Informasi}

Pada tahap ini peneliti mengumpulkan informasi yang digunakan sebagai bahan perancangan prototipe, sehingga diharapkan dapat mengatasi permasalahan yang ada pada siswa tunagrahita dalam pembelajaran matematika. Peneliti mengumpulkan informasi dengan melakukan observasi dan wawancara. Observasi dilakukan dua kali pada saat pembelajaran matematika yaitu satu kali di SMPLB Pelita Hati dan satu lagi di SMPLB Pembina. Setelah melakukan observasi peneliti melakukan wawancara terhadap siswa tunagrahita. Tujuan dilakukan wawancara ini adalah agar peneliti dapat memperoleh informasi mengenai media pembelajaran, permasalahan siswa, serta minat siswa yang digunakan sebagai dasar dalam pengembangan produk.

$$
\text { Pada tahap mengumpulkan }
$$

informasi Kesimpulan dari hasil observasi yang peneliti lakukan pada saat pelajaran matematika peneliti melihat siswa mengalami kesulitan dalam memahami materi pelajaran yang dijelaskan oleh guru dikarenakan siswa tunagrahita sulit dalam berkosentrasi dan sulit berkomunikasi sehingga kebanyak dari siswa tersebut melamun saat proses pembelajaran.
Berdasarkan hasil wawancara terhadap siswa tunagrahita SMPLB Pelita Hati dan SMPLB Pembina di Pekanbaru, maka dapat disimpulkan bahwa siswa mengalami kesulitan dalam memahami pelajaran matematika pada materi bangun ruang. Membedakan titik, garis, dan bidang masih sulit. Kurangnya penggunaan media pembelajaran yang konkret menjadi salah satu penghambat siswa dalam memahami materi yang diajarkan oleh guru.

\section{Tahap Desain Produk}

Pada penelitian ini, peneliti mengembangkan 2 buah kerangka bangun ruang yaitu balok dan kubus agar dapat membantu siswa memahami unsur-unsur pada balok dan kubus, buku petunjuk penggunaan media, lembar validasi media dan angket respon siswa. Pada desain produk ini dimulai dengan membuat sketsa awal dengan menggunakan gambar serta menentukan warna desain menggunakan Microsoft Word.

Desain kerangka balok dan kubus ini menggunakan acrylic yang ditempelkan lampu berwarna kuning untuk menunjukkan bagian titik pada balok dan kubus juga warna biru untuk menunjukkan bagian garis pada balok dan kubus. Peneliti juga menambahkan alat bantu berupa plastik mika yang bisa digunakan untuk menunjukkan bagian bidang pada balok dan kubus. Saklar 1 pada media digunakan untuk menghidupkan lampu berwarna kuning, saklar 2 digunakan untuk menghidupkan lampu berwarna biru, dan saklar 3 digunakan untuk menghidupkan lampu kuning dan biru sekaligus. Pemilihan warna disesuaikan dengan warna yang menarik dan cerah. Perpaduan warna yang cerah dipilih dengan tujuan untuk membedakan bagian titik, garis, dan bidang pada balok dan kubus.

Desain buku petunjuk penggunaan media pembelajaran titik, garis, dan bidang didesain menggunakan Microsoft Word. Buku ini terdiri dari cover, kata pengantar, daftar isi, peta konsep, kopetensi inti dan kopetensi dasar, materi bangun ruang balok dan kubus, pengenalan media TGB, petunjuk pembuatan media, cara menggunakan media, skenario penggunaan 
media dalam proses pembelajaran, lirik lagu yang dapat digunakan sebagai pengenalan media, rencana pelaksanaan pembelajaran, dan daftar pustaka.

\section{Tahap Validasi Desain}

Validasi desain media pembelajaran Titik, Garis, Bidang (TGB) dan buku petunjuk penggunaan media dilakukan secara daring dengan mengirimkan video penggunaan media, buku petunjuk penggunaan media, dan lembar validasi pada tanggal 18 Mei 2020. Validasi dilakukan agar dapat menilai kelayakan media pembelajaran ketika diujicobakan. Hasil validasi media pembelajaran dan buku penggunaan media untuk siswa tunagrahita ringan kelas VIII menggunakan Rating Scale 1-3 kemudian dihitung untuk memperoleh rata-rata penilaian.

Hasil validasi media pembelajaran Titik, Garis, Bidang (TGB) oleh validator tergolong media sudah layak digunakan/ ujicoba lapangan tanpa revisi. Data hasil validasi media pembelajaran TGB sebagai berikut.

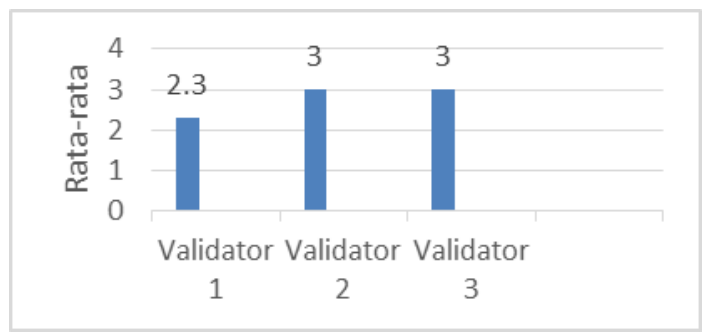

\section{Gambar 1. Hasil Validasi Media Pembelajaran TGB}

\section{Tahap Revisi Desain}

Pada tahap revisi desain peneliti memperoleh komentar dan saran oleh validator untuk memperbaiki buku petunjuk penggunaan media TGB dengan membagi garis menjadi dua yaitu garis horizontal dan garis vertikal.

\section{Tahap Ujicoba Produk}

Peneliti melakukan ujicoba produk untuk siswa tunagrahita SMPLB Pelita Hati dan SMPLB Negeri Pembina Pekanbaru pada hari Selasa 23 Juni 2020. Peneliti melakukan ujicoba produk terhadap dua orang siswa tunagrahita SMPLB Pelita Hati dan satu orang siswa tunagrahita SMPLB Pembina. Pelaksanaan ujicoba dilaksanakan diluar jam pelajaran sekolah dikarenakan pandemic covid-19 sehingga peneliti turun langsung ke tempat tinggal siswa dalam melakukan ujicoba produk.

Setelah melakukan sesi tanya-jawab dan memberikan jawaban yang benar mengenai pertanyaan yang sudah diberikan, maka peneliti mengajak siswa untuk menggunakan media pembelajaran titik, garis, bidang (TGB).

Setelah siswa selesai menggunakan media pembelajaran tersebut, peneliti kemudian membacakan pertanyaan yang terdapat pada lembar angket respon siswa. Hasil respon siswa menunjukkan bahwa produk yang dikembangkan sudah memenuhi kriteria praktis dengan persentase rata-rata $100 \%$.

\section{Pembahasan}

Penelitian ini merupakan penelitian pengembangan yang bertujuan untuk menghasilkan produk berupa media pembelajaran matematika. Hasil penelitian ini berupa hasil pengembangan produk yang meliputi media TGB, dan buku petunjuk penggunaan media pada materi balok dan kubus untuk siswa tunagrahita ringan SMPLB.

Penelitian ini dimulai dari tahap pertama yaitu potensi dan masalah. Pada tahap ini dilakukan wawancara dengan satu orang guru SMPLB-C Pelita Hati Pekanbaru, dua orang guru SMPLB Pembina Pekanbaru, dan satu kepala sekolah SMPLB Pembina Pekanbaru yang selanjutnya potensi dan masalah tersebut dirumuskan dan dianalisis (need analysis). Potensi yang ditemukan dalam penelitian ini adalah kurangnya penggunaan media dalam proses pembelajaran terutama dalam pembelajaran matematika. Masalah yang peneliti temukan yaitu siswa tunagrahita mengalami kesulitan dalam memahami pembelajaran matematika.

Tahap selanjutnya yaitu mengumpulkan informasi. Pada tahap ini peneliti mengumpulkan informasi dengan melakukan observasi dan wawancara. Observasi dilakukan dua kali pada saat 
pembelajaran matematika yaitu satu kali di SMPLB Pelita Hati dan satu lagi di SMPLB Pembina. Setelah melakukan observasi peneliti melakukan wawancara terhadap siswa tunagrahita. Hasil observasi yang peneliti lakukan pada saat pelajaran matematika adalah peneliti melihat siswa mengalami kesulitan dalam memahami materi pelajaran yang dijelaskan oleh guru dikarenakan siswa tunagrahita sulit dalam berkosentrasi dan sulit berkomunikasi sehingga kebanyak dari siswa tersebut melamun saat proses pembelajaran dan hasil wawancara terhadap siswa diperoleh bahwa siswa mengalami kesulitan dalam memahami pelajaran matematika pada mteri bangun ruang, membedakan titik, garis, dan bidang masih sulit, dan kurangnya penggunaan media pembelajaran yang konkret menjadi salah satu penghambat siswa dalam memahami materi yang diajarkan oleh guru.

Pada tahap selanjutnya yaitu tahap desain produk, peneliti Pada penelitian ini, peneliti mengembangkan 2 buah kerangka bangun ruang yaitu balok dan kubus yang terbuat dari acrylic dan diberi lampu agar dapat membantu siswa memahami unsurunsur pada balok dan kubus, buku petunjuk penggunaan media, lembar validasi media dan angket respon siswa. Peneliti juga menambahkan alat bantu berupa plastik mika berwarna merah yang bisa digunakan untuk menunjukkan bagian bidang pada balok dan kubus. Pemilihan warna merah agar media TGB memiliki beragam warna yang menarik. Saklar 1 pada media digunakan untuk menghidupkan lampu berwarna kuning, saklar 2 digunakan untuk menghidupkan lampu berwarna biru, dan saklar 3 digunakan untuk menghidupkan lampu kuning dan biru sekaligus.

Tahap selanjutnya yaitu validasi desain. Media ini divalidasi oleh dua orang dosen pendidikan matematika Universitas Maritim Raja Ali Haji dan satu orang guru tunagrahita SMPLB. Tujuan dari validasi media ini adalah sebagai landasan penelitian untuk melakukan revisi atau perbaikan terhadap media. Jumlah rata-rata penilaian media pembelajaran yang diperoleh dari ketiga validator yaitu 93,33\%. Pada indikator auto-education diperoleh rata-rata skor 2,67 dengan kriteria layak. Pada indikator auto-correction diperoleh rata-rata skor 2,67 dengan kriteria layak. Pada indikator menarik diperoleh rata-rata skor 3 dengan kritera layak. Pada indikator bergradasi diperoleh rata-rata skor 2,84 dengan kriteria layak. Pada indikator kontekstual diperoleh rata-rata skor 2,67 dengan kriteria layak. Dari hasil validasi tersebut dapat disimpulkan bahwa media pembelajaran Titik, Garis, Bidang (TGB) pada materi balok dan kubus untuk siswa tunagrahita ringan SMPLB di Pekanbaru tergolong kategori sangat baik dan valid untuk di ujicobakan. Hal ini sesuai dengan pendapat Sugiyono (2017) yang menyatakan kriteria dalam pengambilan keputusan validasi produk siap dipakai jika penilaian rata-rata validator dikategorikan valid dan sangat valid.

Tahap selanjutnya yaitu revisi desain. Setelah memperoleh saran dari validator maka peneliti memperbaiki buku petunjuk penggunaan media dengan menambahkan penjelasan bagian vertikal dan horizontal pada buku petunjuk.

Tahap keenam yaitu ujicoba produk Media ini diujicobakan kepada dua orang siswa SMPLB Pelita Hati dan satu orang siwa SMPLB Negeri Pembina Pekanbaru. Ujicoba media ini dilakukan dengan mendatangi langsung kediaman siswa dikarenakan sekolah masih diliburkan akibat pandemic covid 19. Dikarenakan siswa tunagrahita mengalami kesulitan dalam membaca dan menulis maka angket respon dibacakan oleh peneliti dan peneliti juga menggunakan rekaman suara saat proses ujicoba produk. Menurut Ristia Havadoh Ervian, dkk (2020) penilaian kelayakan media dari segi kepraktisannya ada dua, praktis secara teori dan praktis secara praktik. Media pembelajaran dikatakan praktis secara teori jika validator menyatakan bahwa media pembelajaran dapat digunakan dengan revisi kecil atau tanpa revisi dan media pembelajaran dikatakan praktis secara praktik jika hasil analisis dari lemabar angket siswa mencapai kategori praktis atau sangat praktis. Jumlah rata-rata yang didapatkan dari pengisian angket respon oleh siswa yaitu $100 \%$. Sehingga dapat disimpulkan 
pengembangan media pembelajaran Titik, Garis, Bidang (TGB) pada materi balok dan kubus untuk siswa tunagrahita ringan telah memenuhi praktis. Hal ini sesuai dengan kategori angket respon siswa terhadap kepraktisan media pembelajaran menurut Sa'dun Akbar (2016) yang menyatakan bahwa jika hasil persentase $85,01 \%-100 \%$ maka media pembelajaran dikategorikan sangat praktis.

Penggunaan media dapat memudahkan siswa tunagrahita ringan dalam memahami materi balok dan kubus. Hal ini sejalan dengan pendapat Riska Prasetya Kalfinta (2018) yang mengembangkan alat peraga matematika dengan model Borg and Gall yang menyatakan bahwa media pembelajaran matematika sifat-sifat bangun ruang dapat membantu siswa tunagrahita dalam mengatasi kesulitan memahami sifat-sifat bangun ruang sehingga dapat membedakan titik, garis dan bidang bangun ruang. Dari uraian hasil validasi dan hasil angket respon siswa terhadap media pembelajaran titik, garis, bidang (TGB) pada materi balok dan kubus untuk siswa tunagrahita kelas VIII, dapat disimpulkan bahwa media tersebut sudah valid dan memenuhi syarat praktikalitas.

\section{Simpulan dan Saran \\ Simpulan}

Penelitian yang telah dilakukan mengenai pengembangan media pembelajaran Titik, Garis, Bidang (TGB) pada materi balok dan kubus untuk siswa tunagrahita ringan SMPLB di Pekanbaru. Produk yang di hasilkan pada penelitian ini yaitu Media pembelajaran Titik, Garis, Bidang (TGB) dan buku petunjuk penggunaan media. Berdasarkan hasil penelitian dan pembahasan diperoleh kesimpulan bahwa media pembelajaran yang dikembangkan pada materi balok dan kubus untuk siswa tunagrahita ringan SMPLB telah memenuhi kriteria valid dan praktis.

\section{Saran}

Peneliti mengalami berbagai kendala maupun keberhasilan dalam melakukan penelitian. Adapun saran yang ingin peneliti berikan yang berhubungan dengan penelitian pengembangan yaitu sebagai berikut.

1. Pada penelitian pengembangan ini peneliti membatasi media pembelajaran yang dikembangkan yaitu materi bangun ruang balok dan kubus untuk siswa kelas VIII SMPLBC. Namun masih terdapat materi dan jenjang tingkatan lain yang dapat dikembangkan menjadi media pembelajaran matematika lainnya.

2. Pada penelitian ini hanya sampai tahap ujicoba kelompok kecil karena keterbatasan waktu akibat pandemic covid-19. Peneliti menyarankan kepada peneliti yang tertarik menindaklanjuti penelitian ini agar melakukan ujicoba pemakaian untuk produk yang dikembangkan.

3. Produk ini telah memenuhi kriteria valid dan praktis sehingga dapat dijadikan salah satu alternatif media pembelajaran untuk digunakan dalam proses pembelajaran.

\section{Daftar Pustaka}

Delphie, Bondan M. A., S. E. (2006). Pembelajaran Anak Berkebutuhan Khusus. Bandung: PT Refika Aditama.

Febrisma, N. (2013). Upaya Meningkatkan Kosakata Melalui Metode Bermain Peran Pada Anak Tunagrahita Ringan ( PTK Kelas DV di SLB Kartini Batam ). Jurnal Ilmiah Pendidikan Khusus 1(2): 109-121.

Fitriyani, Sakur, Maimunah. (2020). Media Pembelajaran Matematika berbasis Komputer pada Materi Kesebangunan dan Kekongruenan bagi Siswa SMP/MTs Kelas IX. Juring (Journal for Research in Mathematics Learning) 3 (1), 081090

Lilik. (2014). Evaluasi Pembelajaran 
Anak Berkebutuhan Khusus (ABK) di Kelas Inklusif di SD Plus Darul 'Ulum Jombang. Jurnal Studi Islam 5(2): 201-228.

Nani Restati Siregar. (2017). Persepsi siswa pada pelajaran matematika: studi pendahuluan pada siswa yang menyenangi game. Prosiding Temu Ilmiah $X$ Ikatan Psikologi Perkambangan Indonesia. 1(1): 224

Riska Prasetya Kalfinta. (2018). Pengembangan alat peraga matematika "SIBARU" untuk siswa berkebutuhan khusus tunagrahita kelas IV SDN $K$ Yogyakarta. Skripsi. Yogyakarta: Universitas Sanata Darma

Ristia Havadoh Ervina, Soffil Widadah, Eka Nurmala Sari Agustina. (2020). Pengembangan media pembelajaran "karjo suwarti" untuk siswa sekolah menengah atas. Jurnal Sigma. 5(2):87-88

Tri Murdiyanto dan Yudi Mahatama. (2014). Pengembangan alat peraga matematika untuk meningkatkan minat dan motivasi belajar matematika siswa sekolah dasar. Jurnal Sarwahita. 11(1): 38

Sa'dun Akbar. (2016). Implementasi Pembelajaran Tematik Sekolah Dasar. Bandung: PT. Remaja Rosdakarya.

Sugiyono. (2017). Metode Penelitian Kantitatif Kualitatif dan $R \& D$. Bandung: Alfabeta

Tjutju Soendari. (2006). Pendekatan Realistik dalam Meningkatkan Kemampuan Matematika Anak Tunagrahita Ringan di Sekolah Luar Biasa. Laporan Penelitian Mandiri. 1(1): 42

Usti. (2013). Meningkatkan Kemampuan Mengenal Angka Melalui Bermain Pancing Angka Bagi Anak Tunagrahita Ringan. Jurnal Ilmiah Pendidikan Khusus I(1), 485 